\title{
REHABILITATION OF LOW VOLUME FLEXIBLE PAVEMENTS BY WHITE TOPPING-A CASE STUDY
}

\author{
Vinay $\mathbf{H}^{\mathbf{1}}$, Sunil $\mathbf{S}^{2}$ \\ ${ }^{1}$ Assistant Professor, Dept of Civil Engg, BGS Institute of Technology, BG Nagar \\ ${ }^{2}$ Assistant Professor, Dept of Civil Engg, Acharya Institute, Soldevanahalli Bangalore
}

\begin{abstract}
In India the nature of overlay treatment in the name of maintenance on flexible pavements is generally Hot Mix Asphalt (HMA) as this technology is in for many years. Lack of interest in selecting different resurfacing alternative is seen in road contractors because of ease in construction of HMA overlay and experience gained by them in construction of HMA overlay. Whitetopping can be a very interesting resurfacing technique for existing asphalt pavements when rutting is the major distress on pavement surface. In the present work an attempt is made to evaluate the structural and functional condition of existing flexible pavements and provide a cost effective rehabilitation solution. A network of six urban roads coming under Tumkur Municipality is selected an extensive field, laboratory investigation, pavement analysis and design of rehabilitation alternative has been carried out. The field work consists of road inventory, traffic studies, MERLIN and BBD studies. PCI is computed based on selected distress parameters (Rut, Patch, Pothole, Cracks). In addition, IRI, BI and characteristics pavement deflections are computed from MERLIN and BBD surveys. Based on PCI, IRI, BI and deflection values pavement rehabilitation measures are considered. The summary of overall condition assessment on functional and structural evaluation in majority of the cases has resulted in 'resurfacing'. In the present study an attempt has been made to design whitetopping section and asphalt overlay as a minor rehabilitation alternative for the in-service flexible pavements. The whitetopping design has resulted in 5 thin whitetopping sections and 1 ultra-thin whitetopping section. Strengthening by asphalt overlay has resulted in different overlay thicknesses for selected roads. Finally cost comparison between whitetopping and asphalt overlay reveals that for majority of selected roads whitetopping proves to be a cost effective rehabilitation solution than the asphalt overlay.
\end{abstract}

Keywords: Whitetopping, Hot Mix Asphalt

\section{INTRODUCTION}

Road building needs huge infrastructure. In case of developing countries, there is a shortage of funds required for new infrastructure projects- both for constructing them and more significantly towards their maintenance and repairs. Most of the existing pavements are flexible in nature having bituminous wearing course. These bituminous pavements, in general, have a problem that they get deteriorated with time. Most of the roads in India exhibit in general, deficiencies like rutting, cracking, potholes etc. Hence before going in for an appropriate rehabilitation, performance evaluation of the existing roads is an absolute necessity.

Whitetopping- a relatively thin concrete overlay placed atop distressed asphalt pavement was introduced in the United States in 1918 and its use has continued through today. In early 1991, a new form of whitetopping named as thin whitetopping (TWT) and ultra-thin whitetopping (UTWT) emerged, which relies on a bond with the distressed pavement to act as a monolithic structure. The first bonded whitetopping sections were constructed in October of 1997 by the Minnesota Department of Transportation (Mn/DOT) on I-94 test sections at the Minnesota Road Research facility
(Mn/ROAD). Demarcation between conventional, thin and ultra-thin whitetopping lies in the thickness of plain cement concrete (PCC) overlay, joint spacing (slab width) and degree to which it is bonded to the existing asphalt layer.

Many investigators have attempted to evaluate performance of whitetopping sections. Ultra-thin whitetopping can be used as an alternative rehabilitation strategy to several developing countries which have a tradition of laying slim asphalt concrete layers (Jose Balbo et al., 2001). Bonded whitetopping can be a viable rehabilitation alternative for distressed asphalt pavements (Vandenbossche et al., 2002). It is necessary to have proper bonding between TWT/UTWT and asphalt, as without it the other design and construction parameters are void (Rodden et al., 2006). Factors like Panel size and thickness will have major effect on the performance of bonded thin concrete overlay (Burnham 2006).

In the present study a network of six urban roads showing signs of distress, coming under Tumkur municipality was selected and a detailed pavement condition assessment was carried out and these roads are designated as R1, R2, R3, R4, R5, and R6. Roads were evaluated both functionally and 
structurally. Pavement condition is computed based on selected distress parameters (Rut, patch, pothole and cracks). In addition, ride quality measurements using MERLINMachine for Evaluating Roughness using Low Cost Instrumentation and characteristics pavement deflection data is collected using Benkelman beam device. Finally based on overall condition assessment rehabilitation alternatives have been designed and cost analysis has been carried out.

\section{DATA COLLECTION AND FIELD STUDIES.}

\subsection{General Data}

Table 1 General Data of the selected roads

\begin{tabular}{|c|c|c|c|c|c|c|}
\hline $\begin{array}{c}\text { Geometr } \\
\text { ic } \\
\text { Features }\end{array}$ & $\overline{\mathbf{R}_{1}}$ & $\overline{\mathbf{R}_{2}}$ & $\mathbf{R}_{3}$ & $\mathbf{R}_{\mathbf{4}}$ & $\mathbf{R}_{5}$ & $\mathbf{R}_{6}$ \\
\hline Length & $300-\mathrm{m}$ & $300-\mathrm{m}$ & 200-m & $\begin{array}{l}600- \\
\mathrm{m}\end{array}$ & $\begin{array}{c}200 \\
-m\end{array}$ & $400-\mathrm{m}$ \\
\hline Width & $\begin{array}{c}3.75- \\
\mathrm{m}\end{array}$ & $\begin{array}{c}3.75- \\
\mathrm{m}\end{array}$ & $\begin{array}{c}3.75- \\
\mathrm{m}\end{array}$ & $\begin{array}{c}7.5- \\
\mathrm{m}\end{array}$ & $\begin{array}{l}3.7 \\
5- \\
m\end{array}$ & $\begin{array}{c}3.75- \\
\mathrm{m}\end{array}$ \\
\hline $\begin{array}{l}\text { Type of } \\
\text { surface }\end{array}$ & $\begin{array}{l}\text { Aspha } \\
\text { lt } \\
\text { concr } \\
\text { ete }\end{array}$ & $\begin{array}{l}\text { Aspha } \\
\text { lt } \\
\text { concr } \\
\text { ete }\end{array}$ & $\begin{array}{l}\text { Aspha } \\
\text { lt } \\
\text { concr } \\
\text { ete }\end{array}$ & $\begin{array}{l}\text { Asph } \\
\text { alt } \\
\text { concr } \\
\text { ete }\end{array}$ & $\begin{array}{c}\text { As } \\
\text { pha } \\
\text { lt } \\
\text { con } \\
\text { cret } \\
\text { e }\end{array}$ & $\begin{array}{l}\text { Aspha } \\
\text { lt } \\
\text { concr } \\
\text { ete }\end{array}$ \\
\hline $\begin{array}{l}\text { Number } \\
\text { of lanes }\end{array}$ & Single & Single & Single & $\begin{array}{c}\text { Doub } \\
\text { le }\end{array}$ & $\begin{array}{l}\text { Sin } \\
\text { gle }\end{array}$ & Single \\
\hline $\begin{array}{c}\text { Divided/ } \\
\text { Undivide } \\
\mathrm{d}\end{array}$ & $\mathrm{U}$ & $\overline{\mathrm{U}}$ & $\overline{\mathrm{U}}$ & $\mathrm{U}$ & $\mathrm{U}$ & $\bar{U}$ \\
\hline $\begin{array}{c}\text { Type of } \\
\text { shoulder }\end{array}$ & $\begin{array}{c}\text { Earthe } \\
n\end{array}$ & $\begin{array}{c}\text { Earthe } \\
n\end{array}$ & $\begin{array}{c}\text { Earthe } \\
n\end{array}$ & $\begin{array}{l}\text { Earth } \\
\text { en }\end{array}$ & $\begin{array}{c}\text { Ear } \\
\text { the } \\
\mathrm{n}\end{array}$ & $\begin{array}{c}\text { Earthe } \\
n\end{array}$ \\
\hline $\begin{array}{c}\text { Shoulder } \\
\text { width }\end{array}$ & $1-\mathrm{m}$ & $1-\mathrm{m}$ & $0.4-\mathrm{m}$ & $\begin{array}{c}1.5- \\
\mathrm{m}\end{array}$ & $\begin{array}{l}0.5 \\
-\mathrm{m} \\
\end{array}$ & $0.5-\mathrm{m}$ \\
\hline $\begin{array}{l}\text { Pavemen } \\
\text { t surface } \\
\text { drainage } \\
\text { condition }\end{array}$ & Poor & Poor & Poor & Poor & $\begin{array}{l}\text { Po } \\
\text { or }\end{array}$ & Poor \\
\hline $\begin{array}{c}\text { Road } \\
\text { side } \\
\text { drainage }\end{array}$ & Poor & Fair & $\begin{array}{c}\text { No } \\
\text { drains }\end{array}$ & Good & $\begin{array}{l}\text { Po } \\
\text { or }\end{array}$ & $\begin{array}{c}\text { No } \\
\text { drains }\end{array}$ \\
\hline $\begin{array}{l}\text { Drainage } \\
\text { width }\end{array}$ & 0.6-m & $0.6-\mathrm{m}$ & - & $\begin{array}{c}0.4- \\
\mathrm{m}\end{array}$ & $\begin{array}{l}0.3 \\
-\mathrm{m}\end{array}$ & - \\
\hline $\begin{array}{l}\text { Land use } \\
\text { pattern }\end{array}$ & $\begin{array}{l}\text { Resid } \\
\text { ential }\end{array}$ & $\begin{array}{l}\text { Resid } \\
\text { ential }\end{array}$ & $\begin{array}{l}\text { Resid } \\
\text { ential }\end{array}$ & $\begin{array}{l}\text { Indus } \\
\text { trial }\end{array}$ & $\begin{array}{l}\mathrm{Ma} \\
\text { rke } \\
\mathrm{t}\end{array}$ & $\begin{array}{l}\text { Resid } \\
\text { ential }\end{array}$ \\
\hline Terrain & Plain & Plain & Plain & Plain & $\begin{array}{l}\text { Pla } \\
\text { in }\end{array}$ & Plain \\
\hline
\end{tabular}

The general data consists of geometric details of the roads which are collected visually walking along the entire stretch. All of these data will remain constant until the pavement undergoes maintenance or repair. The details are as shown in the Table 1.

The sections $R_{3}, R_{6}$ are constructed without road side drainage resulting in water logging during rainy season, exhibiting poor surface drainage condition. $\mathrm{R}_{4}$ exhibits good road side drainage whereas $R_{1}, R_{2}$ and $R_{5}$ have poor surface drainage condition.

\subsection{Existing Crust Details}

When evaluating the condition of existing pavements, it is necessary to know the design features such as the thickness of the pavement component layers. The existing flexible pavements crust thickness were measured by excavating trail pits at the pavement-shoulder interface extending through the pavement layers and up to the level of subgrade. The details are as shown in the Table 2 .

Table 2 Summary of Section Crust Details of Roads

\begin{tabular}{|l|l|l|l|l|l|l|}
\hline $\begin{array}{l}\text { Existing } \\
\text { Layer } \\
\text { Thickness }\end{array}$ & R1 & R2 & R3 & R4 & R5 & R6 \\
\hline $\begin{array}{l}\text { Surface } \\
\text { course }\end{array}$ & 75 & 65 & 70 & 75 & 66 & 73 \\
\hline Base course & 150 & 150 & 120 & 135 & 100 & 200 \\
\hline $\begin{array}{l}\text { Sub-base } \\
\text { course }\end{array}$ & 180 & 210 & 190 & 200 & 120 & 245 \\
\hline $\begin{array}{l}\text { Total } \\
\text { Thickness }\end{array}$ & 405 & 425 & 380 & 410 & 286 & 518 \\
\hline
\end{tabular}

\subsection{Traffic Volume Count}

Traffic census is carried out to analyse the traffic characteristic. For the present study the classified traffic volume study was carried out. A 12 hour traffic volume count for 3 consecutive days was carried out on selected roads referring to IRC: 106-1990. Trucks with more than one rear axle were considered as Multi-axle vehicles. Vehicles like Two wheelers, three wheelers and cars were omitted from the count since they are not considered to be commercial vehicles, which affect the design process. The different vehicle classes were converted to PCU (Passenger Car Unit). Present traffic intensities are expressed in commercial vehicle per day (cvpd). The details are given in Table 3. 
Table 3 Summary of Classified Traffic Survey on Selected Roads

\begin{tabular}{|c|c|c|c|c|c|c|}
\hline Road section & $\mathbf{R}_{\mathbf{1}}$ & $\mathbf{R}_{\mathbf{2}}$ & $\mathbf{R}_{\mathbf{3}}$ & $\mathbf{R}_{\mathbf{4}}$ & $\mathbf{R}_{\mathbf{5}}$ & $\mathbf{R}_{\mathbf{6}}$ \\
\hline $\begin{array}{c}\text { Commercial } \\
\text { Vehicle per day } \\
\text { (ADT) }\end{array}$ & 188 & 237 & 80 & 585 & 134 & 200 \\
\hline
\end{tabular}

\subsection{Pavement Distress Survey}

This is one of the key aspects required for assessing the pavement condition which would help in finding rehabilitation alternatives. In the present work four types of physical distress namely Cracks, Potholes, Patches and rutting were considered. The identification of distress type, severity and amount were done through on-site visual survey referring to ASTM: D64332011. The pavement distress measurements were carried out for every $10-\mathrm{m}$ intervals for the selected roads manually. The measurements collected regarding four distress parameters in the field were used to calculate deduct values (DV), total deduct values (TDV), corrected deduct values (CDV) and Pavement Condition Index (PCI). This PCI which quantifies pavement condition was calculated as per ASTM: D64332011. Pavement condition index value is then used to verbally describe the existing pavement condition. To assess the current adequacy of the pavements, the PCI values obtained for each road were compared with the value ranges of Uday Kumar. et al. (1998), indicating the roads to be rated as good with resurfacing as the possible minor rehabilitation. The study showed that, rutting has been the major distress affecting the roads out of all the four distress parameters. The PCI values of all the selected roads are shown in Table 4.

Table 4 Possible Maintenance based on PCI Values

\begin{tabular}{|c|c|c|c|c|c|c|c|}
\hline $\begin{array}{l}\text { Road } \\
\text { Sectio } \\
\text { n }\end{array}$ & $\begin{array}{l}\text { Pot } \\
\text { hol } \\
\text { es } \\
\text { (D } \\
\text { V) } \\
\end{array}$ & $\begin{array}{l}\text { Patch } \\
\text { es } \\
\text { (DV) }\end{array}$ & $\begin{array}{l}\text { Cra } \\
\text { ck } \\
\text { (DV } \\
\text { ) }\end{array}$ & $\begin{array}{l}\mathbf{R u} \\
\mathbf{t} \\
\mathrm{D} \\
\mathrm{V}\end{array}$ & $\begin{array}{l}\text { PCI } \\
=100 \\
- \\
\mathrm{CD} \\
\mathrm{V} \\
\end{array}$ & $\begin{array}{l}\text { Rati } \\
\text { ng }\end{array}$ & $\begin{array}{l}\text { Type } \\
\text { of } \\
\text { maint } \\
\text { enace }\end{array}$ \\
\hline $\mathrm{R}_{1}$ & 6 & 1 & 3 & 38 & 80 & $\begin{array}{c}\text { Goo } \\
\text { d }\end{array}$ & $\begin{array}{c}\text { Resurf } \\
\text { acing }\end{array}$ \\
\hline $\mathrm{R}_{2}$ & 13 & 2 & 4 & 48 & 70 & $\begin{array}{c}\text { Goo } \\
\text { d }\end{array}$ & $\begin{array}{c}\text { Resurf } \\
\text { acing }\end{array}$ \\
\hline $\mathrm{R}_{3}$ & 8 & 1 & 1 & 25 & 71 & $\begin{array}{c}\text { Goo } \\
\text { d }\end{array}$ & $\begin{array}{c}\text { Resurf } \\
\text { acing }\end{array}$ \\
\hline $\mathrm{R}_{4}$ & 11 & 4 & 3 & 32 & 80 & $\begin{array}{c}\text { Goo } \\
\text { d }\end{array}$ & $\begin{array}{c}\text { Resurf } \\
\text { acing }\end{array}$ \\
\hline $\mathrm{R}_{5}$ & 12 & 3 & 4 & 27 & 78 & $\begin{array}{c}\text { Goo } \\
\text { d }\end{array}$ & $\begin{array}{c}\text { Resurf } \\
\text { acing }\end{array}$ \\
\hline R6 & 10 & 1 & 2 & 30 & 77 & $\begin{array}{l}\text { Goo } \\
\text { d }\end{array}$ & $\begin{array}{l}\text { Resurf } \\
\text { acing }\end{array}$ \\
\hline
\end{tabular}

\subsection{Roughness Measurements}

The graphical plot carried out for the selected road stretches on MERLIN from which roughness ( $\mathrm{D}$ in $\mathrm{mm}$ ) were obtained is used to express roughness in terms of International Roughness Index (IRI). The results of the study were compared with the range of IRI values for different pavements described by Sayers. et al. (1986). The compared results reveal that all the selected roads have IRI values above $6.0 \mathrm{~m} / \mathrm{km}$ which indicates that the roads are having frequent minor depressions, which is true with the existing field condition. The IRI data is given in Table 5. The type of maintenance based on roughness data was found out to be resurfacing. If untreated roughness may affect vehicle operating cost, comfort and safety.

Table 5 Summary of Roughness in terms of IRI

\begin{tabular}{|c|c|c|c|c|}
\hline $\begin{array}{c}\text { Roa } \\
\mathbf{d} \\
\text { Sect } \\
\text { ion }\end{array}$ & $\begin{array}{c}\text { Roughness } \\
\text { on } \\
\text { MERLIN, } \\
\mathbf{D}(\mathbf{m m})\end{array}$ & $\begin{array}{c}\text { IRI } \\
\mathbf{( m / k} \\
\mathbf{m})\end{array}$ & $\begin{array}{c}\text { Pavement } \\
\text { Condition }\end{array}$ & $\begin{array}{c}\text { Type of } \\
\text { maintenan } \\
\text { ce }\end{array}$ \\
\hline $\mathrm{R}_{1}$ & 140 & 7.18 & $\begin{array}{c}\text { Frequent minor } \\
\text { depression }\end{array}$ & Resurfacing \\
\hline $\mathrm{R}_{2}$ & 135 & 6.95 & $\begin{array}{c}\text { Frequent minor } \\
\text { depression }\end{array}$ & Resurfacing \\
\hline $\mathrm{R}_{3}$ & 130 & 6.72 & $\begin{array}{c}\text { Frequent minor } \\
\text { depression }\end{array}$ & Resurfacing \\
\hline $\mathrm{R}_{4}$ & 122 & 6.34 & $\begin{array}{c}\text { Frequent minor } \\
\text { depression }\end{array}$ & Resurfacing \\
\hline $\mathrm{R}_{5}$ & 150 & 7.66 & $\begin{array}{c}\text { Frequent minor } \\
\text { depression }\end{array}$ & Resurfacing \\
\hline $\mathrm{R}_{6}$ & 125 & 6.48 & $\begin{array}{c}\text { Frequent minor } \\
\text { depression }\end{array}$ & Resurfacing \\
\hline
\end{tabular}

\subsection{Deflection Measurements}

The structural adequacy of pavements is ascertained by carrying out deflection testing. For the present study, deflection measurements were done as per IRC: 81-1997. For measuring the pavement deflection CGRA procedure, which is based on testing under static load was adopted. The average characteristic deflection values of the selected roads are shown in Table 6. Since each road exhibits some kind of structural deficiency and the existing crust details are inadequate as per standards to cope up with the present traffic, it may be appropriate to provide maintenance before the pavements undergo complete structural damage.

Table 6 Summary of Deflection Measurement on the Selected Roads

\begin{tabular}{|c|c|c|c|c|c|c|}
\hline Deflection data & \multicolumn{7}{|c|}{ Road Section } \\
\cline { 2 - 7 } & $\mathbf{R}_{\mathbf{1}}$ & $\mathbf{R}_{\mathbf{2}}$ & $\mathbf{R}_{\mathbf{3}}$ & $\mathbf{R}_{\mathbf{4}}$ & $\mathbf{R}_{\mathbf{5}}$ & $\mathbf{R}_{\mathbf{6}}$ \\
\hline Average & 1.20 & 1.20 & 1.28 & 1.76 & 1.69 & 1.11 \\
\hline
\end{tabular}




\begin{tabular}{|c|l|l|l|l|l|l|}
\hline $\begin{array}{c}\text { characteristic } \\
\text { deflection }(\mathrm{mm})\end{array}$ & & & & & & \\
\hline
\end{tabular}

\subsection{Laboratory Investigation}

The laboratory results would help in knowing the properties of materials used in the field at the time of construction. The data collected from the laboratory tests would help in providing proper rehabilitation for the in-service pavements. In the present study, the collected subgrade samples from the road sections were tested for their index and strength properties. The detailed laboratory investigations were carried out on the soil samples in accordance with the procedures followed in Indian standard specifications and the results are presented in Table 7. The existing CBR of $R_{2}$ and $R_{3}$ are very low compared to other roads because of high clay content and plasticity index. Subgrade soils of $R_{1}$ and $R_{5}$ are found out to be the best materials among other soil groups because of their group index values (G.I) being zero.

Table 7 Properties of Existing Subgrade Soil

\begin{tabular}{|c|c|c|c|c|c|c|c|}
\hline $\begin{array}{c}\text { Road } \\
\text { Section }\end{array}$ & \multicolumn{5}{|c|}{ Grain Size } & \multicolumn{3}{c|}{$\begin{array}{c}\text { Atterberg's } \\
\text { Limits }\end{array}$} \\
& \multicolumn{3}{|c|}{} & \multicolumn{3}{|c|}{} \\
\cline { 2 - 9 } & Gravel & Sand & Silt & Clay & LL & PL & PI \\
\hline $\mathrm{R}_{1}$ & 4 & 68 & 22 & 6 & - & NP & - \\
\hline $\mathrm{R}_{2}$ & 1 & 54 & 33 & 12 & 32 & 14 & 18 \\
\hline $\mathrm{R}_{3}$ & 4 & 53 & 31 & 12 & 34 & 18 & 16 \\
\hline $\mathrm{R}_{4}$ & 6 & 67 & 20 & 7 & 35 & 19 & 17 \\
\hline $\mathrm{R}_{5}$ & 3 & 74 & 13 & 10 & - & $\mathrm{NP}$ & - \\
\hline $\mathrm{R}_{6}$ & 3 & 66 & 18 & 13 & 19 & 12 & 7 \\
\hline
\end{tabular}

\begin{tabular}{|c|c|c|c|c|}
\hline \multirow{2}{*}{$\begin{array}{c}\text { Road } \\
\text { Section }\end{array}$} & \multicolumn{3}{|c|}{ Strength Properties } & \multirow{2}{*}{$\begin{array}{c}\text { HRB } \\
\text { Grouping }\end{array}$} \\
\cline { 2 - 4 } & OMC & MDD & CBR & \\
\hline $\mathrm{R}_{1}$ & 11.0 & 2.0 & 6 & $\mathrm{~A}-3$ \\
\hline $\mathrm{R}_{2}$ & 12.0 & 1.97 & 2 & $\mathrm{~A}-6$ \\
\hline $\mathrm{R}_{3}$ & 13.0 & 1.94 & 2 & $\mathrm{~A}-6$ \\
\hline $\mathrm{R}_{4}$ & 11.4 & 1.98 & 5 & $\mathrm{~A}-2-6$ \\
\hline $\mathrm{R}_{5}$ & 8,4 & 2.02 & 10 & $\mathrm{~A}-3$ \\
\hline $\mathrm{R}_{6}$ & 8.6 & 2.15 & 4 & $\mathrm{~A}-2-4$ \\
\hline
\end{tabular}

The overall condition assessment of the pavements has shown that the in-service flexible pavements from the point of distress need resurfacing. The pavements exhibiting frequent minor depressions also need resurfacing to delineate roughness which is affecting the riding quality. These assessments recommend going in for a cost-effective minor rehabilitation design for the existing flexible pavements.

\section{WHITETOPPING DESIGN}

The flexible pavements being low volume urban roads and residential streets showing rutting and roughness, it would be appropriate to go for whitetopping design. The load stress in the critical edge region was obtained as per modified Westergaard's equation by Teller and Sutherland. The kind of overlay thickness and the joints layout obtained for different traffic condition from the design is given in Table 8. The minor rehabilitation design analysis has resulted in 5-Thin whitetopping sections and 1-Ultra-thin whitetopping section. $\mathrm{R}_{6}$ resulted in thinnest overlay of $100-\mathrm{mm}$ with shorter joint spacing $1-\mathrm{m} \times 1-\mathrm{m}$. Whereas, $\mathrm{R}_{4}$ has resulted in thicker overlay of $140-\mathrm{mm}$ with largest joint spacing $1.5-\mathrm{m} \times 1.5-\mathrm{m}$.

Table 8 Design Features of Whitetopping for Selected Roads

\begin{tabular}{|c|c|c|c|c|c|c|c|}
\hline $\begin{array}{c}\text { Roa } \\
\text { d } \\
\text { secti } \\
\text { on }\end{array}$ & $\begin{array}{c}\text { Desi } \\
\text { gn } \\
\text { life } \\
\text { (yea } \\
\text { rs) }\end{array}$ & $\begin{array}{c}\text { Desi } \\
\text { gn } \\
\text { traff } \\
\text { ic } \\
(\mathrm{msa} \\
\text { ) }\end{array}$ & $\begin{array}{c}\text { Typ } \\
\text { e }\end{array}$ & $\begin{array}{c}\text { PCC } \\
\text { thic } \\
\text { knes } \\
\text { S } \\
(\mathrm{mm} \\
\text { ) }\end{array}$ & $\begin{array}{l}\text { HM } \\
\text { A } \\
\text { thic } \\
\text { knes } \\
\text { s } \\
\text { (mm } \\
\text { ) }\end{array}$ & $\begin{array}{c}\text { Pa } \\
\text { ne } \\
\text { l } \\
\text { siz } \\
\text { e } \\
(\mathrm{m} \\
\text { ) }\end{array}$ & $\begin{array}{c}\text { Fib } \\
\text { re } \\
\text { typ } \\
\text { e }\end{array}$ \\
\hline $\mathrm{R}_{1}$ & 30 & 7.86 & $\begin{array}{c}\text { TW } \\
\mathrm{T}\end{array}$ & 120 & 75 & $\begin{array}{c}1 \times \\
1\end{array}$ & $\begin{array}{l}\text { Pol } \\
\text { ypr } \\
\text { opy } \\
\text { lene }\end{array}$ \\
\hline $\mathrm{R}_{2}$ & 30 & $\begin{array}{c}10.9 \\
0\end{array}$ & $\begin{array}{c}\text { TW } \\
\mathrm{T}\end{array}$ & 120 & 65 & $\begin{array}{c}1 . \\
2 \times \\
1 . \\
2\end{array}$ & $\begin{array}{l}\text { Pol } \\
\text { ypr } \\
\text { opy } \\
\text { lene }\end{array}$ \\
\hline $\mathrm{R}_{3}$ & 30 & 3.68 & $\begin{array}{c}\text { TW } \\
\mathrm{T}\end{array}$ & 130 & 70 & $\begin{array}{c}1 \times \\
1\end{array}$ & $\begin{array}{l}\text { Pol } \\
\text { ypr } \\
\text { opy } \\
\text { lene }\end{array}$ \\
\hline $\mathrm{R}_{4}$ & 30 & $\begin{array}{c}26.9 \\
2\end{array}$ & $\begin{array}{c}\text { TW } \\
\mathrm{T}\end{array}$ & 140 & 75 & $\begin{array}{c}1 . \\
5 \times \\
1 . \\
5\end{array}$ & $\begin{array}{l}\text { Pol } \\
\text { ypr } \\
\text { opy } \\
\text { lene }\end{array}$ \\
\hline $\mathrm{R}_{5}$ & 30 & 6.16 & $\begin{array}{c}\text { TW } \\
\mathrm{T}\end{array}$ & 140 & 66 & $\begin{array}{c}1 . \\
2 \times \\
1 . \\
2\end{array}$ & $\begin{array}{l}\text { Pol } \\
\text { ypr } \\
\text { opy } \\
\text { lene }\end{array}$ \\
\hline $\mathrm{R}_{6}$ & 30 & 9.20 & $\begin{array}{c}\text { UT } \\
\text { WT }\end{array}$ & 100 & 73 & $\begin{array}{c}1 \times \\
1\end{array}$ & $\begin{array}{l}\text { Pol } \\
\text { ypr } \\
\text { opy } \\
\text { lene }\end{array}$ \\
\hline
\end{tabular}

The load- related stress in the PCC slabs decreases with the increase in thickness of PCC overlay. $\mathrm{R}_{6}$ with the thinnest overlay $(100-\mathrm{mm})$ and shorter joint spacing $(1-\mathrm{m} \times 1-\mathrm{m})$ has 
resulted in highest critical stress combination. The 120-mm $\left(\mathrm{R}_{1} \& \mathrm{R}_{2}\right)$ overlay with different panel sizes $(1-\mathrm{m} \times 1-\mathrm{m}, 1.2-$ $\mathrm{m} \times 1.2-\mathrm{m})$ shows increase in critical stress combination when compared with the $140-\mathrm{mm}\left(\mathrm{R}_{4} \& \mathrm{R}_{5}\right)$ overlays with the different joint spacing's $(1-\mathrm{m} \times 1-\mathrm{m}, 1.2-\mathrm{m} \times 1.2-\mathrm{m})$. This is because the load-related stress is significantly higher in the thin overlay. But for the same overlay thickness $(120-\mathrm{mm} \&$ $140-\mathrm{mm})$ with different joint spacing $(1-\mathrm{m} \times 1-\mathrm{m}, 1.2-\mathrm{m} \times 1.2-\mathrm{m}$ \& $1-\mathrm{m} \times 1-\mathrm{m}, 1.2-\mathrm{m} \times 1.2 \mathrm{~m})$ the critical stress combination increases with the increase in joint spacing. This is mainly due to increase in warping stresses. The decrease in joint spacing decreases the warping stress. So to ensure better performance of whitetopping sections during their design life factors like short joint spacing and appropriately thick overlays is necessary. Other factors like effective modulus of asphalt base $(\mathrm{K})$, radius of relative stiffness (1) and quality of the bond between the concrete overlay and the asphalt (Reduction in stresses) have a significant effect in arriving at the appropriate thickness and joint spacing of the PCC overlay.

\section{ASPHALT CONCRETE OVERLAY DESIGN}

The selected road stretches were also designed for asphalt overlay based on Benkelman beam deflection studies which were carried out in the field. The IRC: 81-1997 procedure was followed in strengthening the existing flexible pavements by asphalt overlay. The kind of asphalt concrete overlay for the selected roads is presented in Table 9 .

Table 9 Summary of Asphalt Concrete Design for Selected Roads

\begin{tabular}{|c|c|c|c|c|}
\hline $\begin{array}{c}\text { Road } \\
\text { Section }\end{array}$ & $\begin{array}{c}\text { Design } \\
\text { Life } \\
(\text { years })\end{array}$ & $\begin{array}{c}\text { Deflection } \\
(\mathbf{m m})\end{array}$ & ESALs & $\begin{array}{c}\text { Overlay } \\
\text { Thickness } \\
(\mathbf{m m})\end{array}$ \\
\hline $\mathrm{R}_{1}$ & 15 & 1.20 & $\begin{array}{c}5.8 \\
\text { million }\end{array}$ & 55 \\
\hline $\mathrm{R}_{2}$ & 15 & 1.20 & $\begin{array}{c}7.2 \\
\text { million }\end{array}$ & 65 \\
\hline $\mathrm{R}_{3}$ & 15 & 1.28 & $\begin{array}{c}1.0 \\
\text { million }\end{array}$ & 25 \\
\hline $\mathrm{R}_{4}$ & 15 & 1.72 & $\begin{array}{c}9.0 \\
\text { million }\end{array}$ & 150 \\
\hline $\mathrm{R}_{5}$ & 15 & 1.69 & $\begin{array}{c}2.0 \\
\text { million }\end{array}$ & 60 \\
\hline $\mathrm{R}_{6}$ & 15 & 1.11 & $\begin{array}{c}6.0 \\
\text { million }\end{array}$ & 50 \\
\hline
\end{tabular}

The summary of bituminous overlay design reveals that, $\mathbf{R}_{4}$ occupies the highest number of repetitions of axle loads (9.0 million) which has resulted in highest deflection (1.76) requiring the highest overlay thickness (150-mm). But $\mathrm{R}_{3}$ with lowest repetitions of axles (1.0 million) and a characteristic deflection of 1.28 needs the lowest overlay thickness (25$\mathrm{mm}$ ).This indicates that with increase in the repetitions of axles of commercial vehicles and structural inadequacy the overlay thickness needed for strengthening the existing pavement in the form of bituminous concrete also increases.

\section{COST ANALYSIS}

The basic rates for items of works are given in Table 10. The rates are applicable and used for computation of the cost of asphalt concrete overlay as well as of whitetopping. Factors like contingencies cost, escalation cost and traffic diversion cost $(5 \%$ of construction cost) were considered for the bituminous overlay because of the periodic maintenance (every 5 years) to be carried out after the design life. For whitetopping overlay, to achieve the bond between the existing asphalt surface and concrete it is necessary to mill the surface to a certain depth by employing the appropriate milling equipment. The cost of construction of plain cement concrete includes use of high grade of concrete (like M 40) with fibres like polypropylene or polyolefin, laying, compaction, finishing, curing, joint cutting and joint sealing.

Table 10 Basic Rates for Various Items of Works

\begin{tabular}{|c|c|c|}
\hline $\begin{array}{c}\text { Serial } \\
\text { Number }\end{array}$ & Items of Works & $\begin{array}{c}\text { Current } \\
\text { Rates } \\
\text { (Rs) }\end{array}$ \\
\hline 1. & Tack Coat & $17 / \mathrm{m}^{2}$ \\
\hline 2. & Prime Coat & $15 / \mathrm{m}^{2}$ \\
\hline 3. & Bituminous Macadam & $8000 / \mathrm{m}^{3}$ \\
\hline 4. & $\begin{array}{c}\text { Dense Bituminous } \\
\text { Macadam }\end{array}$ & $8500 / \mathrm{m}^{3}$ \\
\hline 5. & $\begin{array}{c}\text { Semi Dense Bituminous } \\
\text { Concrete }\end{array}$ & $9000 / \mathrm{m}^{3}$ \\
\hline 6. & \begin{tabular}{c} 
Bituminous Concrete \\
\hline 7.
\end{tabular} & $\begin{array}{c}\text { Pavement Quality } \\
\text { Concrete }\end{array}$ \\
\hline 8. & Milling /Scarifying & $9500 / \mathrm{m}^{3}$ \\
\hline
\end{tabular}

The cost comparison between whitetopping and asphalt concrete overlay is presented in Table 11. The cost of asphalt concrete overlay for $\mathrm{R}_{4}$ (142.44 lakhs) has worked out to be the highest among other roads while $\mathrm{R}_{3}$ has resulted in lowest cost (9.23 lakhs). The cost ofWhite topping for $\mathrm{R}_{4}(61.61$ lakhs) has worked out to be the highest among others whereas $\mathrm{R}_{3}$ has resulted in lowest cost $(9.57$ lakhs). The costs for construction of thin whitetopping for $R_{1}$ and $R_{2}$ resulted in 
identical cost while for the same roads with the asphalt overlay has resulted in different cost.

White topping for $\mathrm{R}_{4}$ (61.61 lakhs) has worked out to be the highest among others whereas $R_{3}$ has resulted in lowest cost (9.57 lakhs). The costs for construction of thin whitetopping for $R_{1}$ and $R_{2}$ resulted in identical cost while for the same roads with the asphalt overlay has resulted in different cost. The cost of thin whitetopping (9.57 lakhs) for $R_{3}$ is slightly higher than cost of asphalt overlay (9.23) for the same road. The cost of placing of pavement quality concrete (PQC) of required thickness is found to be initially high when compared to laying of asphalt concrete of required. thickness for the roads for that design period respectively

Table 11 Comparative Cost of Asphalt Concrete Overlay versus Whitetopping

\begin{tabular}{|c|c|c|c|c|c|c|}
\hline \multirow[t]{2}{*}{ Scenario } & \multicolumn{6}{|c|}{ Road Section } \\
\hline & $\mathbf{R}_{1}$ & $\mathbf{R}_{2}$ & $\mathbf{R}_{3}$ & $\mathbf{R}_{4}$ & $\mathbf{R}_{5}$ & $\mathbf{R}_{6}$ \\
\hline $\begin{array}{l}\text { Bituminous } \\
\text { Overlay } \\
\text { Thickness } \\
(\mathrm{mm})\end{array}$ & 55 & 65 & 25 & 150 & 60 & 50 \\
\hline $\begin{array}{l}\text { Whitetoppi } \\
\text { ng Type } \\
\text { and } \\
\text { Thickness } \\
(\mathrm{mm})\end{array}$ & $\begin{array}{c}120 \\
\text { (TWT } \\
\text { ) }\end{array}$ & $\begin{array}{c}120 \\
\text { (TWT } \\
\text { ) }\end{array}$ & $\begin{array}{c}130 \\
(\mathrm{TW} \\
\mathrm{T})\end{array}$ & $\begin{array}{c}140 \\
(\mathrm{TW} \\
\mathrm{T})\end{array}$ & $\begin{array}{c}140 \\
(\mathrm{TW} \\
\mathrm{T})\end{array}$ & $\begin{array}{l}100 \\
\text { (UT } \\
\text { WT) }\end{array}$ \\
\hline $\begin{array}{l}\text { Total Cost } \\
\text { of } \\
\text { Bituminous } \\
\text { overlay (Rs } \\
\text { in lakhs) } \\
\end{array}$ & 16.86 & 17.99 & 9.23 & $\begin{array}{c}142 . \\
44\end{array}$ & $\begin{array}{c}11.5 \\
9\end{array}$ & 21.16 \\
\hline $\begin{array}{c}\text { Total Cost } \\
\text { of } \\
\text { Whitetoppi } \\
\text { ng overlay } \\
\text { (Rs in } \\
\text { lakhs) } \\
\end{array}$ & 13.34 & 13.34 & 9.57 & $\begin{array}{c}61.6 \\
1\end{array}$ & $\begin{array}{c}10.2 \\
8\end{array}$ & 14.92 \\
\hline $\begin{array}{c}\text { Saving in } \\
\text { Whitetoppi } \\
\text { ng } \\
\text { (Rs in } \\
\text { lakhs) }\end{array}$ & 3.58 & 3.09 & $\begin{array}{c}- \\
0.34\end{array}$ & $\begin{array}{c}80.8 \\
3\end{array}$ & 1.30 & 6.24 \\
\hline $\begin{array}{l}\text { Saving in } \\
(\%)\end{array}$ & 20.87 & 25.80 & $\begin{array}{c}- \\
3.70\end{array}$ & $\begin{array}{c}56.7 \\
4\end{array}$ & $\begin{array}{c}11.2 \\
0\end{array}$ & 29.48 \\
\hline
\end{tabular}

\section{CONCLUSIONS}

A detailed flexible pavement evaluation has been carried out and the following conclusions are drawn from the present investigation.

1. Rut is the major distress affecting the selected road stretches. Based on PCI and IRI values all road sections require-- "Resurfacing".

2. Based on deflection data and existing crust details, it is found out that the existing flexible pavements are structurally inadequate keeping in mind the present traffic condition. Hence the selected roads need structural overlay.

3. The whitetopping design data shows that, $\mathrm{R}_{6}$ with shorter joint spacing and thinnest overlay has resulted in highest critical stress combination while $\mathrm{R}_{4}$ with thickest overlay and shorter joint spacing has resulted in lowest critical stress combination. Hence as the panel thickness decreases, so too should the overall panel size.

4. From the cost comparison between whitetopping and asphalt overlay, it is observed that, whitetopping design for five roads proves to be cost effective than the asphalt overlay. Whereas on one road the cost of whitetopping is slightly higher than the asphalt concrete overlay. This is due to higher initial cost involved in construction of plain cement concrete on existing asphalt pavement. But once constructed, whitetopping requires little maintenance unlike asphalt concrete overlay which undergoes periodic maintenance.

Hence before implementing any alternative one should perform feasibility studies and life cycle cost analysis to ensure proper decision making.

\section{REFERENCES}

[1]. ASTM: D6433-11 "Standard Practice for Roads and Parking Lots Pavement Condition Index Surveys", 2012, Published by ASTM International, Pennsylvania, United States.

[2]. FHWA, (2003), "Distress Identification Manual for the Long-Term Pavement Performance Program", Publication No.FHWA-RD-03-031, United States.

[3]. Yang H. Huang (2004), "Pavement Analysis and Design", 2nd Edition, University of Kentucky, Published by Pearson Prentice Hall, Upper Saddle River, NJ.

[4]. Sayers, M.W. and Karamihas, S.M. (Oct. 1996) "The Little Book of Profiling- Basic Information about Measuring and Interpreting Road Profiles", Published by the University of Michigan, Ann Arbor, Michigan.

[5]. Cundill, M.A. (1991). "The Merlin Low-Cost Road Roughness Measuring Machine", Transport and Road Research Laboratory, Research Report 301, Berkshire

[6]. FHWA, (2000), "Insights into Pavement Preservation- A Compendium", Federal Highway Administration, U.S Department of Transportation, United States. 
[7]. NCPTC, (2008), "Guide to Concrete overlays Sustainable Solutions for Resurfacing and Rehabilitating Existing Pavements", 2nd Edition, National Concrete Pavement Technology Centre, Iowa State University, Beardshear Hall.

[8]. IRC: SP: 76-2008, "Tentative Guidelines for Conventional, Thin and Ultra-Thin Whitetopping", Published by Indian Roads Congress, 2008, New Delhi.

[9]. NCHRP, (2004), "Guide for Mechanistic-Empirical Design of New and Rehabilitated Pavement Structures, National Cooperative Highway Research Program, Transportation Research Board, Submitted by ARA, Inc., ERES Consultants Division, Illinois.

[10]. AASHTO, (1993), "AASHTO Guide for Design of Pavement Structures" American Association of State Highway and Transportation Officials, Washington, D.C.

\section{BIOGRAPHIES}

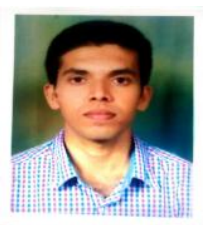

Vinay $\mathrm{H} \mathrm{N}$ is currently working as an Assistant Professor in Civil Engineering Department of BGSIT, B.G. Nagara. He has completed his Bachelor of Engineering in Civil from U.B.D.T.C.E college of Engineering and Post-graduation degree (M.tech) in Transportation Engineering \& Management from Siddaganga Institute of Technology, Tumkur. He has a membership in Instruct, Bangalore.

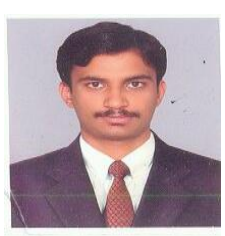

Sunil S is currently working as a Assistant Professor in Acharya Institute in Department of Civil Enggineering. Having a ecperience of 1year in teaching field. He has completed his Bachelor of Engineering in Civil from Govt Enggineering college Hassan and Postgraduation degree in Transportation Engineering \& Management from Siddaganga Institute of Technology, Tumkur. 